\title{
Peran Dan Pentingnya Fosil Bagi Ilmu Pengetahuan
}

\section{Harry Widianto}

Keywords: ecofact, fossils, definition, education, prehistory, theory

\section{How to Cite:}

Widianto, H. (2006). Peran Dan Pentingnya Fosil Bagi Ilmu Pengetahuan. Berkala Arkeologi, 26(1), 77-85. https:/ / doi.org/10.30883/jba.v26i1.926

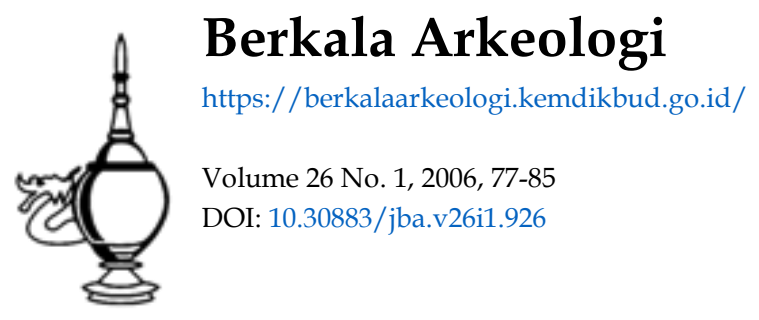

\section{c) (i) (5)}

This work is licensed under a Creative Commons Attribution-NonCommercial-ShareAlike 4.0 International License. 


\section{PERAN DAN PENTINGNYA FOSIL BAGI ILMU PENGETAHUAN Harry Widianto}

Salah satu persepsi masyarakat luas mengenai pengertian sebuah fosil dalam kehidupan sehari-hari — antara lain - adalah barang-barang kuna ataupun purbakala. Benak masyarakat luas lebih mudah mengkaitkan pengertian fosil dengan sesuatu yang antik dan berkonteks masa lalu. Sebagian dari persepsi tersebut benar, akan tetapi sesungguhnya sebuah fosil mempunyai pengertian yang lebih luas dan lebih spesifik. Oleh karena itu, persepsi masyarakat tentang fosil di atas baru merupakan pengertian awal — sebagian dari keseluruhan pengertian- -yang masih jauh dari pengertian sebuah fosil yang sebenarnya, sehingga masih harus dilengkapi dengan pengertian-pengertian yang lebih sempurna. Dalam konteks tersebut di atas, tulisan ini akan mencoba memberikan beberapa pemahaman mengenai fosil dan seluk-beluknya, sehingga dapat dihindari persepsi masyarakat tentang pengertian fosil yangkurang pas.

\section{Batasan Fosil}

Dalam konotasi arkeologis, fosil dimasukkan sebagai data arkeologi yang berupa ekofak (ecofact). Pengertian dari ekofak ini adalah benda arkeologi yang berasal dari komponen orgamik, yang merupakan sisa-sisa dari mahluk hidup, dan oleh karenanya, dapat dipindahkan. Selain ekofak, data arkeologi lainnya adalah artefak (artifacts), yaitu peralatan yang dibuat oleh manusia dan dapat dipindahkan, dan juga fitur (feature) : benda buatan manusia atau alam, yang dapat mencerminkan aktivitas manusia di masa lalu, dan tidak dapat dipindahkan karena besar, berat, ataupun akan menjadi rusak (apabila dipindahkan). Berdasarkan pengelompokan data arkeologi tersebut di atas, maka fosil adalah salah satu data ekofak, yang dapat berasal dari sisa-sisa organik, baik dari manusia, hewan, ataupun tumbuh-tumbuhan.

Kata fosil berasal dari kata Latin fodere, yang berarti : menggali. Oleh karena itu, fosil sangat berkaitan dengan "sesuatu yang berada di dalam tanah, dan untuk 
mendapatkannya harus menggali'. Hal ini berarti bahwa fosil sangat erat kaitannya dengan sesuatu yang telah terkubur beberapa lama. Antara tahun 1550-1800, sangat lazim dikenal bahwa semua benda-benda yang diperoleh harus melalui penggalian, disebut fosil, baik yang asalnya berupa mineral ataupun sisa-sisa binatang (Casanova, 1960). Dalam batasannya, fosil diartikan sebagai : "semua sisa-sisa, jejak, ataupun cetakan dari manusia, binatang, dan tumbuhtumbuhan yang telah terawetkan dalam suatu endapan batuan dari masa geologis atau prasejarah yang telah berlalu" (Bates and Jackson, 1984). Batasan tersebut merupakan batasan dalam artian luas (sensu lato), karena di dalamnya tercakup pula "jejak" maupun "cetakan". Di lain pihak - yang lebih banyak dikenal - adalah batasan secara lebih sempit (sensu stricto), yang hanya mencantumkan sisa-sisa manusia, hewan, dan tumbuh-tumbuhan. Oleh karena harus terendapkan dalam masa geologis atau prasejarah yang telah berlalu, maka sebuah fosil harus diperhitungkan dalam ribuan tahun. Sebagai bandingan, masa geologis yang paling muda adalah Kala Holosen, yang telah mulai sejak 11.000 tahun yang lalu hingga saat ini. Di lain pihak, masa prasejarah sangatlah panjang, dapat mencapai jutaan tahun, yang di Indonesia baru berakhir pada abad ke-4 Masehi.

\section{Proses Pembentukan Fosil}

Ada beberapa hal yang harus ada dan terjadi, sehingga komponen manusia, binatang, dan tumbuh-tumbuhan tersebut dapat disebut sebagai fosil. Proses sebuah tulang atau kayu menjadi fosil, dikenal dengan istilah fosilisasi. Proses fosilisasi ini tergantung pada beberapa faktor. Pertama, adalah "bahan baku" (raw material), yang harus berupa komponen organik dari mahluk hidup, yaitu manusia, binatang, dan tumbuh-tumbuh. Bahan yang dapat tertinggal sebagai fosil adalah bahan-bahan yang keras. Di kalangan tumbuh-tumbuhan, yang paling memungkinkan adalah ranting, dahan, atau batang kayu itu sendiri. Di kalangan manusia dan hewan, hanya phenotypus-nya (tulang-belulangnya) saja yang dapat tertinggal sebagai fosil, sedangkan genothypus-nya (komponen ciri genetis) tidak lagi dapat diamati. Oleh karena itu, komponen keraslah-misalnya tulang dan kayuyang dapat menjadi fosil. 
Kedua, sisa-sisa manusia, hewan, dan tumbuh-tumbuhan tersebut harus diendapkan dalam suatu lingkungan pengendapan yang memungkinkan sebuah tulang atau kayu menjadi fosil. Meski "bahan baku" tersebut mempunyai peluang yang sama untuk menjadi fosil, tidak semuanya dapat dijamin menjadi fosil. Terdapat lingkungan pengendapan tertentu yang sangat memungkinkan dipakai sebagai media menjadi fosil, misalnya endapan volkanik atau lingkungan kapur. Akan tetapi, tidak sedikit pula terdapat lingkungan pengendapan yang tidak memungkinkan terjadinya proses fosilisasi, sebagai misal adalah lingkungan rawa yang banyak mengandung asam. Di lingkungan asam, betapa pun kerasnya sisa manusia atau binatang seperti gigi, akan musnah dan tidak terawetkan. Sebaliknya, di lingkungan yang banyak mengandung silika atau kwarsa, proses fosilisasi akan lebih cepat terjadi.

Ketiga, adalah faktor masa (waktu) yang diperlukan sebuah tulang atau kayu menjadi fosil. Dalam suatu lingkungan pengendapan yang sangat baik, misalnya pada endapan gravel volkanik, diperlukan waktu minimal 7.000 tahun untuk proses fosilisasi. Sebaliknya, untuk endapan yang kurang baik sebagai media proses fosilisasi, misalnya lempung hasil pelapukan batuan, akan memerlukan waktu yang lebih lama.

Oleh karena itu, proses fosilisasi akan tergantung pada 3 faktor utama: materi yang berupa materi organik (tulang atau kayu), media lingkungan pengendapan yang baik, dan minimal waktu 7.000 tahun. Proses fosilisasi tersebut akhimya dapat didefinisikan sebagai : proses berubahnya komponen organik dalam suatu tulang atau kayu menjadi komponen anorganik yang berupa mineral, yang berasal dari lingkungan pengendapannya. Dalam hal ini, komponen organik akan terurai dan digantikan oleh mineral-mineral yang terdapat di endapan sekelilingnya. Struktur (bentuk) tulang atau kayu tidak berubah sama sekali, tetapi yang berubah adalah tekstur (komposisi) nya. Mineral-mineral yang umum menggantikan komponen organik dari suatu tulang atau kayu adalah : silika, quartz, kalsium karbonat, dan pyrites besi. Dalam proses fosilisasi ini akan terjadi kondisi umum : tulang atau kayu bertambah menjadi keras dan berat. Pada saat semua komponen organik berganti menjadi anorganik, maka proses fosilisasi itu telah berjalan secara sempurna, dan sebuah tulang atau kayu dapat disebut sebagai 
fosil, yang memerlukan waktu minimal 7.000 tahun. Ketika proses fosilisasi telah terjadi tetapi komponen organik belum sepenuhnya digantikan menjadi komponen anorganik, maka tulang atau kayu tersebut belum dapat dikatakan sebagai sebuah fosil, melainkan masih sub-fosil.

\section{* Yang Harus Dilakukan Terhadap Temuan Fosil}

Di lapangan, sangat jarang seekor binatang purba dari Kala Plestosen Tengah sekitar 500.000 tahun lalu yang oleh karena kepurbaannya telah menjadi fosil misalnya badak (Rhinoceros sp.), gajah purba (Stegodon trigonocephalus), atau pun seekor kijang (Cervus lydekkeri) - ditemukan secara utuh. Sampai saat ini, hampir-hampir tidak pernah ditemukan seekor binatang purba secara utuh dengan masing-masing tulang masih dalam posisi anatomisnya. Suatu kenyataan yang lebih sering terjadi adalah penemuan fosil - baik fosil manusia, binatang, dan tumbuhtumbuhan - dalam keadaan fragmenter, telah terpotong-potong dalam ukuran yang lebih kecil. Penyebab utama dari situasi penemuan fosil yang seperti ini adalah : proses transportasi dari suatu tempat ke tempat lainnya sebagai suatu pelapukan fisik, yang terjadi selama ratusan ribu tahun. Seekor binatang atau bahkan manusia yang mati 500.000 tahun yang lalu akan tercerai-berai tulang-belulangnya akibat erosi atau transportasi fluviatil misalnya, dan masing-masing tulangnya akan diendapkan secara berulang di berbagai tempat yang berbeda. Proses transportasi tersebut tidak saja akan mencerai-beraikan setiap komponen tulang, tetapi sering kali bahkan sampai membuat patah sebuah tulang menjadi beberapa bagian.

Lokasi-lokasi penemuan fosil yang paling efisien adalah endapan-endapan volkanik atau satuan karst, yang menurut ciri stratigrafis dan sedimentasinya, berasal dari endapan Plestosen dan Pliosen, dengan kisaran usia antara 2 juta tahun (atau lebih), hingga 11.000 tahun yang lalu. Endapan jenis ini-misalnya alur Pegunungan Kendeng dan jajaran Gunung Sewu - adalah tempat-tempat potensial penemuan fosil. Tebing-tebing yang terpotong oleh alur sungai, lereng-lereng yang tererosi, ataupun singkapan-singkapan tanah lainnya merupakan tempat yang paling mudah ditemukannya fosil. Oleh karena eksistensinya yang selalu terendapkan di dalam tanah dalam waktu yang sangat lama, sangat sering sekali sebuah fosil tersingkap ke permukaan tanah dalam kondisi basah atau lembab. Apabila keadaan ini yang 
terjadi di lapangan, maka biarkan fosil tersebut menjadi kering tanpa dikenai sinar matahari langsung, baik secara sengaja atau tidak, tetapi cukup diangin-anginkan di tempat teduh hingga kering. Panas langsung matahari justru akan memberikan akibat yang tidak diinginkan, fosil bahkan akan menjadi retak dan pecah dalam potongan yang lebih kecil.

Manakala telah diperoleh kondisi yang kering, maka perlu dilakukan pembersihan fosil dari sedimen yang masih melekat padanya. Dalam situasi pasir lepas sebagai materi pengendapnya seperti halnya fosil-fosil yang ditemukan dari Formasi Kabuh dan Notopuro di Sangiran, ataupun Formasi Kabuh di Kedungbrubus, maka pembersihan cukup dilakukan dengan kuas saja, yang besarkecilnya ukuran kuas disesuaikan dengan besar-kecilnya fosil yang ditemukan. Ada kalanya pula, fosil-fosil tersebut ditemukan di endapan yang lebih keras dan kompak -misalnya gravel konglomeratan grenzbank di Sangiran atau pun breksi laharik di Gunung Butak - maka diperlukan alat-alat pembersih lainnya, seperti pin-set kedokteran gigi, yang tujuannya masih tetap sama, yaitu membersihkan fosil dari materi pengendapnya. Pada fase ini, fosil sudah dalam keadaan bersih dan solid.

Selanjutnya dilakukan upaya rekonstruksi ke arah bentuk aslinya, merekatkan satu fragmen dengan fragmen lainnya pada posisi pecahan yang tepat. Pada prinsipnya hanya melakukan perekatan antara satu fragmen dengan fragmen lainnya, yang kedua permukaan yang akan direkatkan harus benar-benar dalam keadaan bersih dan kering. Apabila telah diyakini bahwa dua potong fosil merupakan pasangannya, maka perekatan dapat dilakukan secara permanen dengan memakai super glue atau alteco. Untuk sebuah tukang yang telah mengalami fosilisasi secara sempurna, maka alteco atau super glue tidak akan memberikan efek negatif terhadap fosil tersebut. Selanjutnya perlu dilakukan rekonstruksi anatomis untuk merangkai satu tulang dengan tulang lainnya, di mana pekerjaan ini hanya dapat dilakukan oleh seorang ahli yang mengetahui anatomi tulang. Setelah rekonstruksi selesai (baik seluruhnya, sebagian besar, atau bahkan sebagian keeil), maka selanjutnya adalah menentukan jenis binatang atau manusianya yang akan dilakukan oleh para spesialis, minimal menyangkut genus dan spesies. 


\section{* Manfaat Fosil bagi Ilmu Pengetahuan}

Satu hal yang pasti adalah : fosil berkaitan dengan kehidupan masa lalu. Oleh karena itu, mempelajari sebuah fosil pada hakekatnya juga mempelajari kehidupan masa lalu, baik yang menyangkut kehidupan manusia secara langsung ataupun tidak langsung. Menyangkut kehidupan manusia secara langsung apabila yang dipelajari adalah fosil manusia, yang di Indonesia terdiri atas fosil-fosil Homo erectus dari berbagai tingkatan evolusinya, Meganthropus paleojavanicus, atau bahkan Homo sapiens arkaik. Akibatnya, dipahami bahwa proses evolusi manusia Indonesia ini tidak mendadak terjadi demikian saja sebagai Homo sapiens seperti sekarang ini, tetapi telah mengalami proses evolusi fisik yang sangat panjang, minimal sejak 1.5 juta tahun yang lalu. Dalam hal ini, bumi Jawa dikenal sebagai tempat yang sangat dihormati di dunia, karena dari pulau ini saja telah ditemukan lebih dari 100 individu manusia purba Homo erectus, yang menunjukkan lebih dari 50 $\%$ populasi Homo erectus di dunia. Temuan terakhir Homo florensiensis, yang lebih suka saya sebut sebagai Homo sapiens floresiensis (Widianto, 2004), merupakan temuan spektakuler yang sangat menggoncang dunia hingga saat ini, dan sangat penting bagi ilmu pengetahuan, karena dia dapat memberikan sinar terang bagi tahap evolusi manusia dari Homo erectus ke Homo sapiens pada kurun 18.000 hingga 30.000 tahun lalu, tidak saja untuk Indonesia tetapi juga untuk dunia.

Di lain pihak, fosil-fosil binatang maupun tumbuhan juga sangat berharga bagi ilmu pengetahuan, karena darinya dapat diketahui evolusi faunal dari suatu lingkungan hidup manusia. Bukti-bukti faunal menunjukkan adanya kondisi evolutif yang berbeda di suatu tempat tertentu pada suatu masa tertentu. Penelitian terhadap fosil-fosil binatang di Jawa menunjukkan miskinnya spesies pada Kala Plestosen Bawah sekitar 1.5 juta tahun yang lalu, yang hanya didominasi antara lain oleh Tetralophodon bumiajuensis (sejenis gajah) di bagian bawah lapisan Kali Glagah di Bumiayu, dan mungkin, dalam bagian lempung hitam Pucangan di Sangiran. Fosil lainnya adalah Hexaprotodon simplex (sejenis kuda nil), Cervidae (sejenis rusa) dan Geochelone (kura-kura raksasa)(Soondaar, 1981). Pada sekitar 1.2 juta tahun lalu, ketiganya punah dan digantikan oleh Stegodon trigonocephalus dan Hexaprotodon sivalensis (gajah dan kuda nil yang lebih modem), bersamaan 
dengan munculnya Bovidae (sapi, banteng, dan kerbau) untuk pertama kali, dan mungkin juga Panthera trinilensis (sejenis macan)(de Vos et al., 1993). Suatu koleksi fosil, yaitu suatu asosiasi mamalia, akan mempunyai nilai ilmiah yang lebih tinggi jika dapat dihubungkan dengan lansekap vegetasi hasil studi palinologi, dan apabila umur mutlak flora dan fauna tersebut dapat ditentukan melalui pertanggalan metode geofisika. Lingkungan hidup manusia purba itu akan menjadi terang dan jelas di depan kita setelah melalui analisis-analisis yang panjang dari para spesialis, sehingga masa lalu manusia dapat diketahui secara lebih jelas pula... Dari buktibukti temuan fosil itulah -baik fosil manusia ataupun binatang dan tumbuhandiketahui pula jati diri bangsa Indonesia yang lebih jelas, yang sudah muncul di Bumi Jawa sejak 1.5 juta tahun yang lalu dan berevolusi hingga mencapai Homo sapiens sapiens seperti sekarang ini.

\section{* Situs-situs Kontibutor Fosil Manusia}

Sangat sedikit tempat-tempat di dunia ini-tidak lebih dari jari satu tangan--yang mempunyai potensi fosil seperti di Jawa, yang menyebabkan Jawa telah dianggap sebagai tempat terhormat karena merupakan salah satu pusat evolusi manusia di dunia. Lokasi tempat penemuan fosil manusia dan juga binatang yang utama di Jawa adalah (Widianto, 1993) :

Situs Sangiran (Sragen dan Karanganyar) : merupakan kontributor utama dari penemuan fosil manusia purba Homo erectus, yang hidup di situs ini antara 1.5 hingga 0.3 juta tahun yang lalu, yang mencakup tahapan evolutif Homo erectus arkaik dan Homo erectus tipik. Selain itu, di situs ini juga mempunyai potensi luar biasa akan temuan fosil binatang, yang telah berevolusi lebih lama sejak 1.8 juta tahun yang lalu, dan berdampingan hidup dengan manusia purba Sangiran pada Kala Plestosen Bawah dan Plestosen Tengah.

* Situs Kedungbrubus (Madiun) : adalah situs pertama ketika Homo erectus ditemukan di Indonesia pada tahun 1890 leh Eugène Dubois, dalam endapan pasir fluvio-volkanik bagian dari endapan Plestosen Tengah di Pegunungan Kendeng. Pada Iapisan pengandung fosil manusia ini (Horison Atas), juga ditemukan konsentrasi fosil binatang yang dikenal sebagai bagian dari Fauna Trinil, sementara 
di bagian bawahnya, pada Horison Bawah, ditemukan pula seri fosil binatang yang lebih tua, 1.8 juta tahun.

Situs Trinil : merupakan situs historis penemuan Homo erectus pertama di dunia oleh Eugene Dubois tahun 1891, yang saat itu disebut dengan Pithecanthropus erectus, berusia Plestosen Tengah, lebih dari 500.000 tahun. Dalam endapan yang sama, ditemukan pula berbagai fosil binatang yang sangat tipik dari Kala Plestosen Tengah, yang disebut dengan Fauna Trinil.

* Situs Ngandong (Blora) : Fosil-fosil Ngandong yang berupa 12 tengkorak manusia dan beberapa infra-kranial, ditemukan dalam sistem teras di tepi Bengawan Solo, yang posisi stratigrafi aslinya tidak diketahui. Akibatnya, usia fosil ini tidak dapat secara pasti diketahui, akan tetapi morfologi kranialnya menunjukkan Homo erectus yang paling akhir hidup di Jawa, jenis Homo erectus progresif, sekitar 200.000 tahun yang lalu. Selain fosil manusia, ditemukan pula himpunan fosil binatang yang sangat tipik dari akhir Kala Plestosen Tengah, yang disebut sebagai Fauna Ngandong.

* Situs Sambungmacan (Sragen) : menghasilkan 3 atap tengkorak Homo erectus progresif, setara dengan fosil manusia dari Ngandong, dalam endapan purba Pegunungan Kendeng yang ditoreh oleh Bengawan Solo. Seperti halnya Ngandong, berbagai fosil binatang juga ditemukan di Sambungmacan.

* Situs Ngawi : sebuah tengkorak Homo erectus progresif yang sangat bagus, telah ditemukan di pinggir Bengawan Solo di Desa Selopuro, yang sama sekali di luar konteks stratigrafis. Jenisnya sama dengan fosil manusia dari Ngandong dan Sambungmaean.

* Situs Perning (Mojokerto) : sebuah tengkorak Homo erectus arkaik, berupa tengkorak anak-anak berumur 3-5 tahun, ditemukan dari endapan volkanik berupa pasir konglomeratan berusia 1.8 juta tahun, bersama-sama dengan berbagai jenis fosil binatang yang diklasifikasikan sebagai Fauna Jetis. Berdasarkan pertanggalan tersebut, hamper pasti bahwa fosil anak-anak ini, merupakan fosil Homo erectus 
paling purba di Indonesia.

Situs Patiayam (Pati) : berada di kaki Gunung Muria. Di salah satu bukitnya, Gunung Slumprit, terdapat konkresi breksi volkanik yang diikuti oleh puluhan meter pasir dan lempung tufaan. Di lapisan ini telah ditemukan fragmen tulang tengkorak dan gigi-geligi manusia, berusia sekitar 700.000 tahun.

\section{DAFTAR PUSTAKA}

Bates, Robert I., and Julia A. Jackson, 1984. Dictionary of Geological Times. New York: Anchor Press Books.

Casanova, Richard, 1960. Fossil Collecting, An Illustrated Guide. London :Faber and Faber.

-De Vos, John, F. Aziz, P.Y Sondaar, 1993. "Les faunes de quaternaires de Java", Les Dossiers d'Archéologie, no. 184 : 56-61.

Sondaar, P.Y., 1981. "The geochelon faunas of the Indonesia Archipelago and their paleogeographical and biostratigraphical significance", Modern Quaternary Research in Southeast Asia, 6: pp. 111-120.

Widianto, Harry, 1993. "Unité et Diversité des Hominidés de Java : Présentation de Restes Humains Fossiles Inédits", Desertasi. Paris : Institut de Paléontologie Humaine, Muséum National d'Histoire Naturelle : 284 halaman.

Widianto, Harry, 2004. "Siapakah Dia, Homo floresiensis?", Kompas 5 November 2004. 